연구노트

\title{
Analysis of quality characteristics for food ingredients using fine powder of Jeju citrus
}

\author{
Hee-Jeong Choi ${ }^{1}$, Jeong-Sic $\mathrm{Ra}^{1}$, Shin-Kyo Chung ${ }^{1,2}$, Sang-Han Lee ${ }^{1,2 *}$ \\ ${ }^{1}$ School of Food Science and Technology, Kyungpook National University, Daegu 41566, Korea \\ ${ }^{2}$ Food and Bio-Industry Research Institute, Kyungpook National University Daegu 41566, Korea
}

\section{제주 감귤의 미세분말을 이용한 식품소재로서의 품질특성 분석}

\author{
최희정 ${ }^{1} \cdot$ 라정식 $^{1} \cdot$ 정신교 ${ }^{1,2} \cdot$ 이상한 $^{1,2 *}$, \\ 1경북대학교 식품공학부 식품생물공학전공, ${ }^{2}$ 경북대학교 식품생물산업연구소
}

\begin{abstract}
In order to assess whether the fine powder of Jeju citrus can be used for better quality characteristics in food processing, we first prepared ultra-fine powder C20 (20 mesh of citrus), C40 (40 mesh of citrus), and C100 (100 mesh of citrus). The mean particle size of $\mathrm{C20}, \mathrm{C} 40$, and $\mathrm{C} 100$ were $662.6 \pm 176.9,344.6 \pm 126.8$, and 91.7 \pm 54.9 $\mu \mathrm{m}$, respectively. The antioxidant activity measured by the 2,2-Diphenyl-1-picrylhydrazyl (DPPH) and 2,2' -Azino-bis(3-ethylbenzothiazoline-6-sulfonic acid) diammonium salt (ABTS) radical scavenging assay and ferric Reducing Antioxidant Power (FRAP) assay was the highest in C100. Moreover, increasing mesh of citrus increased the $L^{*}$ and $b^{*}$ values of citrus, but not the $a^{*}$ value of citrus. Using a prototype developed from the powder, we performed sensory tests for taste, color, texture, flavor and overall preference. C100 showed the highest score compared to $\mathrm{C20}$ and $\mathrm{C40}$ in the sensory evaluation. Particularly, C100 had excellent flavor among all the powders. Our results collectively indicate that the Jeju citrus supplementation has better quality characteristics during food processing; this may aid in the development of food ingredients for functional food materials. Furthermore, a high mesh of citrus provides better quality in citrus-based food processing.
\end{abstract}

Key words : citrus, anti-oxidant, sensory evaluation, quality, fine powder

\section{서 론}

감귤(Citrus reticulata Blanco, Citrus reticulata (Blanco) var. erythrosa)은 특이한 맛과 향기를 보유한 과일로서, 특히 flavonoid로 분류된 hesperidin, neohesperidin 및 naringin 등 이 주요 향기성분이라 알려져 왔다(1-2). 감귤류 플라보노 이드의 기능성에 대한 연구로는 항산화/항염증 작용(3), 고 지혈증 억제작용(4), 충치예방 효과(5)와 naringin의 항균효 과(6), hesperidin의 혈압강화 효과(7) 등이 보고되었다. 또

*Corresponding author. E-mail : sang@knu.ac.kr

Phone : 053-950-7754, Fax : 053-950-6772

Received 16 April 2019; Revised 23 May 2019; Accepted 03 June 2019.

Copyright (c) The Korean Society of Food Preservation. All rights reserved.
한 항암 효과를 가지는 quercetin, kaempferol, myricetin, apigenin, luteolin, limonin, 및 nomilin 등에 대한 연구가 많 이 수행되었다(8). 최근에는 감귤류의 암 예방물질에 관한 연구가 활발히 진행되면서 flavone류 중 polymethoxyflavone 류가 감귤류에 특이적으로 발견되어 혈소판 응집억제, 임 파구 증식억제, 항궤양, 항염증 등의 생리 활성을 보유한다 는 보고도 있다(9).

한편, 미세분말은 물질의 표면적을 극대화하여 용해도를 높임으로서 이를 이용할시 식품이나 바이오산업에서 활용 도가 증진되는 장점을 가지며, 상대적으로 유용물질의 추 출이 용이하고, 색이나 향기 등의 파괴를 줄이는 소재로서, 이의 분쇄 중 저온을 유지함으로써 파우더의 분쇄 중 색감 과 향기를 최대한 유지시켜 주는 장점이 있다(10). 최근 출시된 미세 분말을 이용한 음료의 경우를 보아도 목 넘김 이나 복용 편이성, 건강기능성이 강조됨으로써 판매가 늘 
어나고 있는 실정이다(10). 일반적으로 음료 등에 첨가가 가능한 입자의 크기는 직경이 $3 \mu \mathrm{m}$ 이하인데, 이는 침강속 도와 Brownian운동에 의한 전이거리의 상관관계에 따라 달라질 수 있다(11). 점성이 높고 당분함량이 많은 경우에 는, 이의 분말화는 기존 기술로는 미세화가 불가능하므로 이에 관련한 기술을 확립할 필요가 있다고 보고되어 있다 (12). 이런 미세 분말화 기술의 개발은 여러 가지 농산물을 1 차 가공품에서 탈피하여 용해도를 증진 즉, 체내 흡수율을 높이는 기능성 식품소재나 식의약 소재 등 고부가가치 소재 로의 전환이 가능하도록 할 것으로 기대된다 $(13,14)$.

본 연구는 제주 감귤의 소비를 촉진하기 위하여 관광식 품을 개발하게 되었으며, 그 일환으로 감귤의 미세 분말을 이용한 가공적성에 대하여 연구하였기에 이에 보고하는 바이다.

\section{재료 및 방법}

\section{실험재료}

본 실험에 사용된 감귤(Citrus reticulata (Blanco) var. erythrosa)은 제주자치특별도 소재의 (주제주자연과친환경 영농조합법인에서 유기농업에 의하여 재배한 농산물로서, 이의 voucher specimen은 경북대 식품효소생물공학연구실 에 보관 중(2016-Cr)이며, 이의 진위여부는 경북대학교 식 물생명과학전공, 제주대학교 아열대식물연구소 및 대구약 전골목의 대훈약업사에서 확인하였다.

\section{미세분말 조제}

먼저, 감귤을 일정크기로 분류하고 흐르는 tap water로 3회 세척한 후, slicer (HKP - 05, Korea Energy Tech. Co., Ltd., Seoul, Korea)로 세절하고 열풍건조기 (Venticell 111R, $\mathrm{GS}, \mathrm{USA}$ )로 50 도에서 24 시간 동안 건조과정을 거치고 이 를 다시 분쇄기(Hanil Industrial Co., Seoul, Korea)에서 $8,000 \mathrm{rpm}$ 으로 20 분간 분쇄하여 분말을 분취하였다. 다음, 이를 각각의 standard sieve $(20,40,100$ mesh)로 통과시켜서 통과한 분말을 최종적으로 각 mesh의 sample로 사용하였 다.

\section{미세분말의 입도분석}

미세분말의 입도분석을 위하여 먼저, 공시재료의 분산재 는 증류수를 사용하였고, $2 \mathrm{~g}$ 의 시료를 분취하고 동량의 분산제를 첨가하고 1 분간 분산시킨 후, 이를 3 회 반복하고 입도분석은 Particle size analyzer (Beckman Coulter N5/LC13320 , Boulevard Brea, CA, USA)를 사용하였다(12).

DPPH (1,1-Diphenyl-2-picrylhydrazyl) 항산화 활성 각 입도추출물 시료에 $0.2 \mathrm{mM} \mathrm{DPPH}$ (1,1-Diphenyl- 2-picrylhydrazyl)와 DPPH solution을 $1 / 20$ 의 비율로 해서 실온서 10분간 반응시킨 후 $517 \mathrm{~nm}$ (Victor 3, Perkin Elmer, Turku, Finland)에서 흡광도를 측정하였다. DPPH radical 소거활성 비율(\% inhibition)은 아래의 계산식과 같이 계산 하였다(15).

$$
\text { Inhibition }(\%)=\left[\text { Acontrlo }-\frac{\text { Asample }}{\text { Acontrol }}\right] \times 100
$$

(A: Absorbance O.D. $517 \mathrm{~nm}$ )

Ferric ion reducing antioxidant power (FRAP) 항산화 활성

반응액으로 acetate buffer (pH 3.6, $300 \mathrm{mM}$ ): $10 \mathrm{mM}$ 의 TPTZ (2,4,6-tripyridyl-s-triazine): $20 \mathrm{mM}$ 의 $\mathrm{FeCl}_{3} \cdot 6 \mathrm{H}_{2} \mathrm{O}$ 를 10:1:1의 비율로 실험직전에 혼합하여 만들었다. 반응액과 추출물을 각각의 비율로 혼합한 후 10 분간 상온에서 보관 후 $595 \mathrm{~nm}$ 에서 흡광도를 측정하였다(16).

\section{ABTS 활성}

$\operatorname{Re}$ 등(15)의 방법에 따라 $7.4 \mathrm{mM}$ ABTS[2,2'-azinobis (3-ethylbenzothiazoline-6-sulfonic acid) diammonium salt]와 $2.6 \mathrm{mM}$ potassium persulfate를 혼합하여 실온 - 암소에서 24시간 동안 방치하여 radical을 형성시킨다. 그 후 실험 직전에 $\mathrm{ABTS}$ 용액을 $732 \mathrm{~nm}$ 에서 흡광도가 $0.700 \pm 0.030$ 이 되도록 phosphate buffer saline(PBS, pH 7.4)로 희석하여 사용하였다. 희석된 용액 $950 \mu \mathrm{L}$ 에 각 샘플 $50 \mu \mathrm{L}$ 를 가하여 암소에서 10 분간 반응시킨 후 $732 \mathrm{~nm}$ 에서 흡광도를 측정하 였으며 계산식, ABTS radical scavenging ability $(\%)=100-$ [(OD of sample/ OD of control $) \times 100]$ 에 의하여 활성을 산출 하였다(17).

\section{관능검사 및 선호도}

경북대학교 식품공학부 대학원생 중에서 무작위로 15 명 의 sensory panel로 구성하고 감귤의 미세분말 에 대하여 선호도를 평가하였다(18). 각 샘플에 무작위 순서로 3자리 숫자를 사용하여 임의로 코딩된 각 숫자를 부여하고 색상, 향미, 맛, 질감 및 전반적인 선호도에 대한 품질특성을 평가 하였다. 패널 참여자들은 5 점 척도법 $(5=$ 매우 우수, 4 = 비교적 우수, $3=$ 양호, 2 = 미미함, 1 = 싫어함 를 사용하여 선호도를 평가하였다. 패널은 샘플을 담은 트레이, 물 한 컵, 설문지를 받고, 샘플 사이에서는 반드시 미각을 헹구도 록 권장하였으며, 샘플과 설문지를 처리할 충분한 공간이 주어졌으며 평가시간은 제한되지 않았고, 패널에게는 특별 한 보상은 주어지지 않았으며 경북대학교 생명 윤리위원회 의(IRB)의 가이드라인을 준수하였다(2019-0112).

\section{통계분석}

각 실험에 이용된 그룹 간 통계처리결과는 엑셀프로그램 
을 사용하여 SD (standard deviation) 값을 구하여 산정하였 으며, student t-test의 검정에 의한 값으로 $\mathrm{p}<0.05$ 수준의 값을 산정하였다(19).

\section{결과 및 고찰}

\section{제주감귤분말의 입도별 크기}

Fig. 1 에서 보는 바와 같이 $20,40,100$ mesh별 평균 입자 의 크기는 particle size analyzer에 의하여 분석한 결과, 각각 $662.6+176.9,344.6+126.8,91.7+54.9 \mu \mathrm{m}$ 이었다. 이는 sieve 의 크기가 촘촘할수록 mesh별 평균 입자의 크기가 작은 것을 알 수 있었으며, 분말의 성상은 mesh가 증가할수록 분말의 색상이 이의 입자를 이용하여 다음의 실험을 수행하 였다.

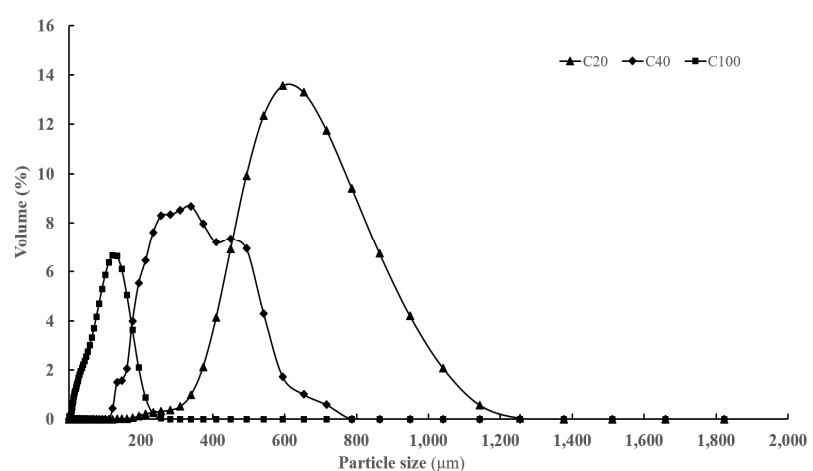

Fig. 1. Particle size distribution of Citrus reticulata (Blanco) var. erythrosa.

\section{색도 제주감귤분말의 입도별 $\mathrm{L}^{*}, \mathrm{a}^{*}, \mathrm{~b}^{*}$ 값의 분석}

미세분말화에 따른 감귤의 색도변화는 품질의 특성에 큰 변화를 나타내기 때문에 입자크기에 따른 감귤분말의 색도를 측정하였다. 그 결과, Fig. 2에서 보는 바와 같이 명도값은 $\mathrm{L}^{*}$ (lightness)의 경우 20, 40, 100 mesh로 증가함에 따라 $64.73 \pm 1.20,64.79 \pm 0.32,76.45 \pm 1.33$ 으로 증가하였고, $\mathrm{b}^{*}$ (yellowness)의 경우에도 $30.16 \pm 0.91,34.51 \pm 0.96,53.51$ \pm 1.18 으로 증가하였으나 $\mathrm{a}^{*}$ (redness)는 차이를 나타내지 않았다.

\section{(A)}
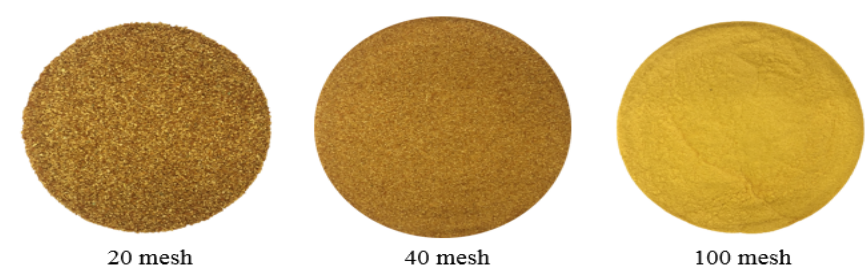

\section{제주감귤분말의 항산화 활성}

다음에는 이의 분말을 이용하여 항산화 활성에 어떤 영 향을 미치는지에 대하여 조사하였다(Fig. 3). 이미 전보(12) 에서 감의 미세분말을 이용한 항산화 및 항아토피 활성을 연구한 경험을 바탕으로 각 분말에 대하여 항산화 활성을 측정하여 보았다. 분말의 입자크기가 20에서 $100 \mathrm{mesh}$ 로 증가함에 따라 DPPH radical scavenging 활성의 경우에는 $14.8 \%$ 에서 $18.3 \%$ 로 약간 증가하였으며, FRAP assay의 경 우에도 $2.5 \mu \mathrm{mol} / \mathrm{g}$ 에서 $3.5 \mu \mathrm{mol} / \mathrm{g}$ 로, 그리고 ABTS radical scavenging assay의 경우에도 $22.6 \%$ 에서 $28.9 \%$ 로 증가하는 양상을 나타내었다. 미세 분말은 물질의 표면적을 극대화 하여 난분해성 물질의 용해도를 높임으로서 용해도가 높아 지는 장점을 가지며, 상대적으로 유용물질의 추출이 용이 하고, 색이나 향기 등의 파괴를 줄일 수 있는 장점이 있다. 이는 전보(12)에서 확인하였듯이, 감의 경우에도 미세분말 의 정도가 미세할수록 항염 및 항아토피의 활성이 증가한다 는 보고와 유사한 양상을 보였으나, 본 연구결과에서는 그 입자의 정도가 20-100 mesh로서 다소 입자의 정도가 큰 차이를 나타내지 못하여 결과에서의 차이가 현저하지 않았 다. Kim 등(13)은 양갱을 조제시 입도별 홍화씨를 미세분말 의 정도차이로서 품질특성을 분석한 바, $20,35,45,60$ mesh 별 입자의 크기가 작아질수록 종합선호도에 있어서 상승한 다는 보고와 유사한 패턴을 나타내었으나, 항산화활성에 대한 결과는 제시하지 않았다. 유사한 연구로서 제주산 감 태의 미세분말에서 입도가 증가할수록 항산화 활성이 다소 증가하는 것을 보고한 것과 유사한 경향을 보였다(14).

\section{제주감귤분말의 관능검사 결과}

이상의 결과를 토대로 각 분말별로 관능검사를 통하여 선호도를 측정하여 보았다. 입자의 mesh별 감귤분말의 선 호도를 검사함으로서 향후 시제품이나 제품생산에 기초자 료로 사용하기 위하여 15 인의 panelist의 관능 평가 항목을 외관, 맛, 색깔, 향기, 조직감, 및 종합선호도를 5 점 척도법을 이용하여 관능적 특성이 우수할수록 높은 점수를 부여하여 선호도를 최종 판단하였다. 그 결과, 외관, 맛, 색깔, 향기, 조직감, 및 종합적 선호도에 있어서 $20 \mathrm{mesh}$ 보다는 $40 \mathrm{mesh}$

(B)

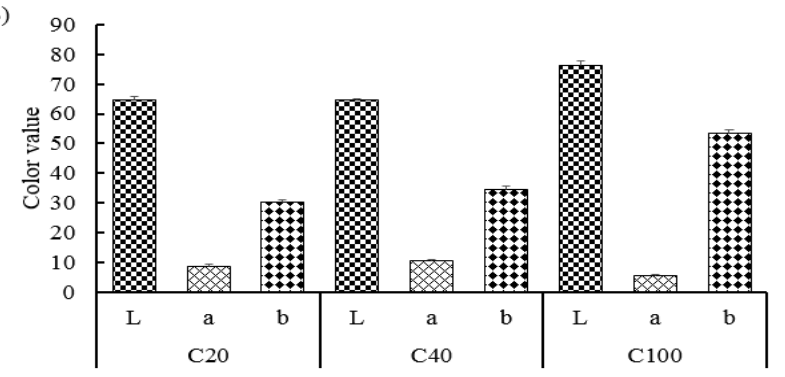

Fig. 2. Hunter color of Citrus reticulata (Blanco) var. erythrosa (A) Pictures of each particle size of Citrus reticulata (Blanco) var. erythrosa and (B) Color degree of each particle L : Lightness, a : Redness, $b$ : Yellowness 
(A)

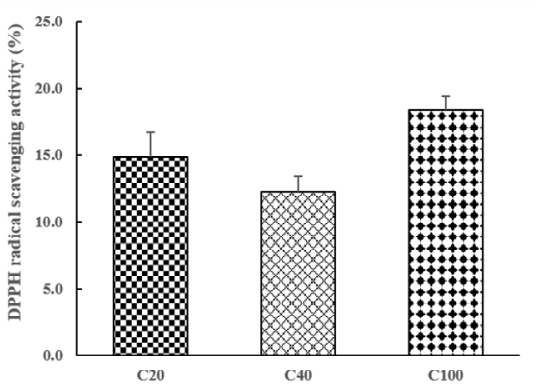

(B)

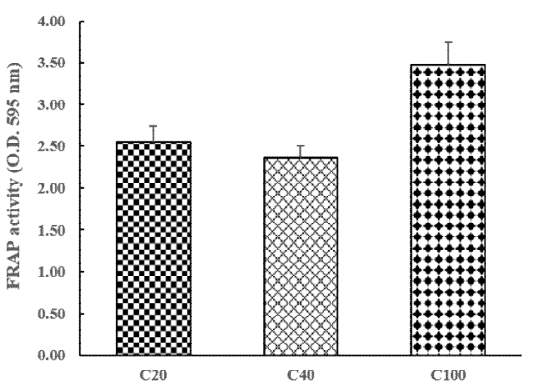

(C)

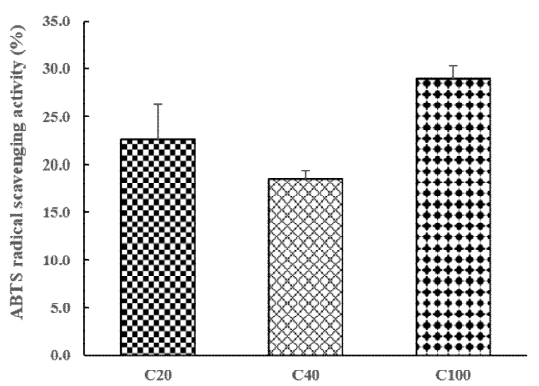

Fig. 3. Antioxidant activities of Citrus reticulata (Blanco) var. erythrosa with different particle size measured by DPPH (A), FRAP (B) and ABTS radical scavenging assay (C).

에서, $40 \mathrm{mesh}$ 보다는 $100 \mathrm{mesh}$ 에서 우수한 점수를 획득하 였다(Fig. 4). 특히, 향기의 경우에는 $100 \mathrm{mesh}$ 에서 가장 높게 나타남을 알 수 있었는데, 이는 전체적인 선호도에도 상당한 영향을 미쳤다고 판단된다. 한편, 감귤이 외의 식품 소재의 경우를 적용해 본 결과에 의하면 이와는 다소 다른 연구결과를 얻었다. 제주의 특산물인 톳의 경우에도 이와 같은 방법으로 분말을 조제하여 이의 관능검사를 실시한 결과, mesh가 증가할수록 향기는 더 이취가 강하며 $(3.5,2.8$, $2.5)$, 맛도 감소(3.0, 2.7, 2.8)함을 알 수 있었으나, 조직감은 약간 상승하는 경향 $(1.5,2.7,3.2)$ 을 나타내어 전체적인 선 호도(3.3, 3.5, 3.6)는 크게 차이가 없었다. 본 연구의 최종 목표가 지역의 특산물인 제주감귤을 이용한 관광식품의 개발이라는 측면에서 보면, 이와 같이 식품의 소재를 분말 화(또는 초미세 분말화)함으로서 품질특성이 증진된다면 이는 상당히 의미가 있는 결과로 판단되어진다. 일반적으 로 분말의 미세화가 증가할수록 항산화활성은 증가하면서 종합적 선호도가 증가하는 반면, 제조공정 중 비산하는 등 의 문제는 여전히 방해요인으로 지적된다. 감귤분말을 조 제시 슬라이서와 열풍건조기를 통하고 분쇄기에서 파쇄를 하였음에도 입자사이에 trap되어 있는 flavonoid나 terpene 계통의 방향성분이 20에서 $100 \mathrm{mesh}$ 로 입자가 미세할수록 이들 잔존성분이 더 많이 외부로 유리되었음을 발견하였

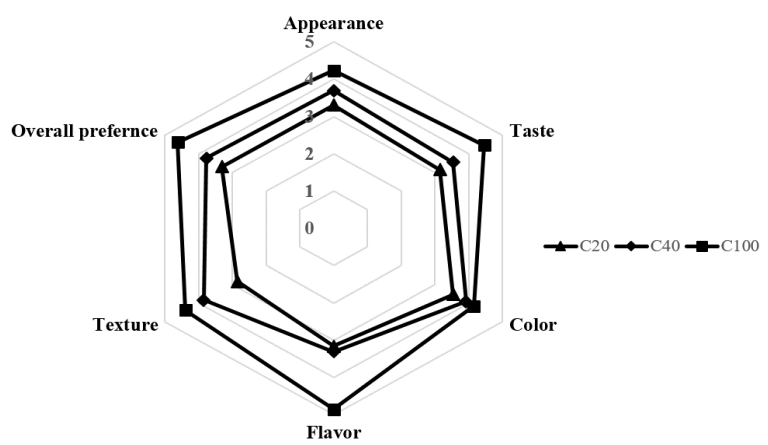

Fig. 4. Sensory evaluation of Citrus reticulata (Blanco) var. erythrosa.
다. 향후 관광식품의 시조제에는 $100 \mathrm{mesh}$ 의 감귤분말을 첨가하여 조제한다면 더욱 우수한 품질을 담보할 수 있다는 발견에 큰 기대를 걸 수 있다.

\section{요 약}

제주도에서 생산한 감귤의 소비를 촉진시키고 다양한 가공식품을 개발함으로써 생산자에게 이익을 증진시키기 일환으로 먼저 감귤을 입도별로 $20 \mathrm{mesh}, 40 \mathrm{mesh}, 100$ mesh로 분쇄하여 이의 활성을 확인하였다. 먼저, particle size analyzer를 이용하여 입도분석을 진행 한 결과, 20 mesh 에서 $662.6 \pm 176.9,40 \mathrm{mesh}$ 에서 $344.6 \pm 126.8$, 그리고 100 mesh에서 $91.7 \pm 54.9$ 값이 나타났다. 입도별 항산화 효과를 확인하기 위하여 DPPH, FRAP, ABTS 소거 활성 실험을 진행하였다. 항산화능을 측정한 결과, 입도가 미세할수록 항산화 활성이 증가함을 확인할 수 있었다. 색도 $\left(\mathrm{L}^{*}, \mathrm{a}^{*}\right.$, $\mathrm{b}^{*}$ )를 측정하였을 때, 입도가 미세할수록 $\mathrm{L}^{*}$ 값과 $\mathrm{b}^{*}$ 값이 증가하였으나, $\mathrm{a}^{*}$ 값의 경우 입자크기별 큰 변화가 나타나 지 않음을 확인 할 수 있었다. 또한, 관능평가 결과, 미세한 입도일수록 품질에 미치는 영향이 우수함을 확인할 수 있었 다. 이상의 결과로부터 제주 감귤분말은 식품소재나 바이 오소재로 광범위하게 적용시 품질의 증진에 기여할 수 있음 을 확인하였다.

\section{감사의 글}

이 논문은 산업통상자원부 지역산업육성사업(R0005865) 의 지원에 의하여 수행되었습니다.

\section{References}

1. Rhyu MR, Kim EY, Bae IY, Park YK (2002) Contents 
of naringin, hesperidin and neohesperidin in premature Korean citrus fruits. Korean J Food Sci Technol, 34, 132-135

2. Hyon JS, Kang SM, Han SW, Kang MC, Oh MC, Oh CK, Kim DW, Jeon YJ, Kim SH (2009) Flavonoid component changes and antioxidant activities of fermented citrus grandis Osbeck peel. J Korean Soc Food Sci Nutr, 38, 1310-1316

3. Hyun JM, Park KJ, Kim SS, Park SM, Lee YJ, An HJ (2015) Antioxidant and anti-inflammatory effects of solvent fractions from the peel of the native Jeju citrus 'Hongkyool' and 'Pyunkyool'. J Life Sci, 25, 1132-1138

4. Park HJ, Jung UJ, Cho SJ, Jung HK, Shim S, Choi MS (2013) Citrus unshiu peel extract ameliorates hyperglycemia and hepatic steatosis by altering inflammation and hepatic glucose- and lipid-regulating enzymes in mice. J Nutr Biochem, 24, 419-427

5. Park YM, Kim SJ, Jo KH, Yang EJ, Jeong ST (2006) Anticariogenic and antioxidant activities from medicinal herbs. J Korean Soc Food Sci Nutr, 35, 284-293

6. Ozcelik B, Kartal M, Orhan I (2011) Cytotoxicity, antiviral and antimicrobial activities of alkaloids, flavonoids, and phenolic acids. Pharm Biol, 49, 396-402

7. Ohtsuki K, Abe A, Mitsuzumi H, Kondo M, Uemura K, Iwasaki Y, Kondo Y (2002) Effects of long-term administration of hesperidin and glucosyl hesperidin to spontaneously hypertensive rats. J Nutr Sci Vitaminol, 48, 420-422.

8. Yu J, Wang L, Walzem R L. Miller E G, Pike L M, Patil B S (2005) Antioxidant activity of citrus limonoids, flavonoids, and coumarins. J Agric Food Chem, 53, 2009-2014

9. Li S, Lo C Y, Ho C T (2006) Hydroxylated polymethoxyflavones and methylated flavonoids in sweet orange (Citrus sinensis) peel. J Agric Food Chem, 54, $4176-4185$

10. Park DJ, Ku KH, Kim SH (1996) Characteristics and application of defatted soybean meal fractions obtained by microparticulation/air-classification. Korean J Food Sci Technol, 28, 497-505
11. Yeo EJ, Son MH, Kim JH, Yoo YE, Kim KO, Yoon JS (2018) A study on the relationship between the behavior of liquid droplet and the arrangement of microparticles within the droplet. Korean Soc Mech, 42, 215-219

12. Heo JC, Lee KY, Lee BG, Choi SY, Lee SH, Lee SH (2010) Anti-Allergic activities of ultra-fine powder from Persimmon. Korean J Food Preserv, 17, 145-150

13. Kim JH, Park JH, Park SD, Kim JK, Kang WW, Moon KD (2002) Effect of addition of various mesh sifted powders from safflower seed on quality characteristic of Yangeng. Korean J Food Preserv, 9, 309-313

14. Jung EY, Lee SK (2007) Anti-oxidant activities and regeneration effect in HaCaT cell line by Jeju Island aboriginal Eclonia cava. J Korean Soc Cosmetol, 13, 1071-1077

15. Brand-Williams W, Cuvelier ME, Berset C (1995) Use of a free radical method to evaluate antioxidant activity. LWT-Food Sci Technol, 28, 25-30

16. Heo JC, Park JY, Hwang JS, Park HC, Kang SW, Hwang SJ, Yun CY, Kwon TK, Lee SH (2006) Comparison of in vitro antioxidant activity and cyclooxygenase-2 promoter inhibitory activity in Harmonia axyridis Pallas and Coccinella septempunctata Linne. Korean J Food Preserv, 13, 513-518

17. Re R, Pellegrini N, Proteggente A, Pannala A, Yang M, Rice-Evans C (1999) Antioxidant activity applying an improved ABTS radical cation decolorization assay. Free Radical Bio Med, 26, 1231-1237

18. Lee JM, Kang BH, Lee SH (2009) Analysis of quality change during preservation by a prototype drink containing a Helianthus annuus seed extract. Korean J Food Preserv, 16, 299-303

19. Heo JC, Park JY, Kwon TK, Chung SK, Kim SU, Lee SH (2005) Development of high throughput screening techniques using food-borne library against anti-asthma agents. Korean J Food Preserv, 12, 267-274 